\title{
COMPARATIVE TRIAL OF THE EFFECT OF RANITIDINE AND CIMETIDINE ON GASTRIC SECRETION IN FASTING PATIENTS AT INDUCTION OF ANAESTHESIA
}

\author{
J.M. DuRrant and L. STRunin
}

\begin{abstract}
A comparative trial of the $\mathrm{H}_{2}$-receptor antagonists, cimetidine and ranitidine, on gastric $\mathrm{pH}$ and volume, was conducted in 168 healthy patients coming to elective surgery. The drugs were administered in random fashion either intravenously (ranitidine $50 \mathrm{mg}$ or $100 \mathrm{mg}$, cimetidine $300 \mathrm{mg}$ or placebo) or orally (ranitidine $150 \mathrm{mg}$, cimetidine $300 \mathrm{mg}$ or placebo). The patients received the drugs or placebo 45 minutes to five hours before operation. After induction of anaesthesia, a nasogastric tube was passed and the stomach contents were aspirated. The volume and $\mathrm{pH}$ were measured. Those patients receiving ranitidine 50 or 100 $\mathrm{mg}$ or cimetidine $300 \mathrm{mg}$ intravenously had statistically significantly higher gastric $\mathrm{pH}$ compared to those receiving placebo, but up to eight percent of patients had a $\mathrm{pH}$ less than 2.5. Oral administration of cimetidine $300 \mathrm{mg}$ or ranitidine $150 \mathrm{mg}$ were also superior when compared to placebo. However, 25 per cent of the patients receiving oral cimetidine had a $\mathrm{pH}$ less than 2.5; cimetidine orally was statistically significantly inferior to ranitidine 100 $\mathrm{mg}$ given intravenously. We conclude that the intravenous use of either ranitidine or cimetidine is an acceptable method to decrease the acidity of gastric contents before induction of anaesthesia. Orally, ranitidine appears to be a better choice than cimetidine in the doses studied. Both ranitidine and cimetidine need to be given at least 45 minutes before induction of anaesthesia to be effective; therefore the use of these agents to decrease the risk of acid pulmonary aspiration syndrome by no means obviates the need for proper anaesthesia technique during induction of anaesthesia.
\end{abstract}

KeY WORDS: ANTACIDS, ranitidine, cimetidine; CoMPliCaTIONS, lung, acid aspiration, prophylaxis.

\section{INTRODUCTION}

PULMONARY ASPIRATION of gastric contents may be associated with induction of general anaesthesia and was first described in pregnant women by Mendelson in 1946. ${ }^{1}$ Experimental studies in animals have shown that the severity of this complication is due to the acidic nature of the inhaled material and may also be related to the use of intermittent positive pressure ventilation in the treatment of the aspiration. It has been suggested that if the gastric $\mathrm{pH}$ can be raised above 2.5 , or possibly even $3.5,{ }^{2}$ and the gastric volume can be reduced to less than $25 \mathrm{ml}$, then the pulmonary acid aspiration syndrome may be avoided. In the past the only practical method of raising the gastric $\mathrm{pH}$ has been by oral ingestion of antacids by patients before operation. ${ }^{3}$ The regime needs to be applied rigorously and many

J.M. Durrant, M.D., C.R.C.P.(C), Senior Resjdent; L. Strunin, M.D., F.F.A.R.C.S., F.R.C.P.(C), Professor and Director; Department of Anaesthesia, Foothills Hospital, 140329 th Street N.W., Calgary, Alberta, Canada, T2N 2T9. patients find the taking of mist. magnesium trisilicate, the compound most frequently advocated, somewhat unpalatable. In addition, since no oral antacid has been shown to be totally effective, the usual measures to prevent regurgitation must also be employed. ${ }^{4}$

The recent introduction of $\mathrm{H}_{2}$-receptor antagonists has led to a series of trials involving the first of these agents, cimetidine, which has been shown to raise gastric $\mathrm{pH}$ to the accepted value both by oral and intravenous dosing. 3.5 Ranitidine is a new $\mathbf{H}_{2}$-receptor antagonist, currently undergoing limited clinical trials in Canada and differs from cimetidine by being a substituted amino alkyl furan without an imidazole ring. Studies in man have suggested that ranitidine is a more active $\mathrm{H}_{2}$-receptor antagonist than cimetidine, being approximately 4 to 7 times more potent on a molar basis, ${ }^{6,7}$ and is thought to have fewer side effects. The onset and duration of action of cimetidine and ranitidine are reported to be similar and the maximum gastric inhibitory effect of both drugs reaches peak effect 60 to 75 minutes after intravenous injection. ${ }^{8}$

Can. Anaesth. Soc. J., vol. 29, no. 5, September 1982 
In the present study, cimetidine and ranitidine were given intravenously and orally and compared with a placebo (intravenous- 0.9 per cent normal saline; oral-lactose tablet identical in formulation to ranitidine) with respect to inhibition of gastric secretion in fasting patients at induction of anaesthesia.

\section{METHODS}

One hundred and sixty-eight (168) patients (ages 16 to 72 years), ASA class 1 and 2, were studied. Fifteen additional patients were excluded from the study because of the inability to obtain a gastric sample, either due to inadequate gastric volume with the gastric tube in place or inability to pass the tube into the stomach. All patients studied had a general anaesthetic requiring tracheal intubation for general surgical, orthopaedic, gynaecological or plastic surgical procedures. Written informed consent was obtained from each patient on the evening before operation and approval for the study was obtained from the Ethics and Research \& Development Committees of the Foothills Hospital, Calgary. Exclusions from the study included any patient with a weight of less than 50 kilograms or more than 90 kilograms; any patient with kidney or liver disease; any patient with known sensitivities to $\mathrm{H}_{2}$-receptor antagonists; any patient with gastrointestinal disease or who was already taking any antacid substance.

Patients were assigned randomly to one of seven groups of equal size $(n=24)$. The patients received either ranitidine $50 \mathrm{mg}$ or $100 \mathrm{mg}$, cimetidine $300 \mathrm{mg}$ or placebo as an intravenous agent, or ranitidine $150 \mathrm{mg}$, cimetidine $300 \mathrm{mg}$ or a placebo orally. The groups were comparable with respect to age and type of surgery (Table I).

All patients had fasted at least eight hours before induction of anaesthesia. Each patient received diazepam 0.1 to $0.2 \mathrm{mg} \cdot \mathrm{kg}^{-1}$ as oral premedication approximately two hours before induction of anaesthesia. The drugs studied were given intravenously through an indwelling catheter, 45 minutes to three hours before operation, or were given orally from one and one half to five hours preoperatively, the test drug being taken with a sip of water (1ess than $30 \mathrm{ml}$ ).

Induction of anaesthesia was accomplished with thiopentone 4 to $6 \mathrm{mg} \cdot \mathrm{kg}^{-1}$ intravenously, followed by a neuromuscular blocking drug, either succinylcholine, pancuronium or d-tubocurarine. A nasogastric tube (\#16 Salem sump) was inserted into the stomach immediately after
TABLE I

\begin{tabular}{|c|c|c|c|c|c|}
\hline \multirow[b]{2}{*}{ Group } & \multicolumn{2}{|c|}{ ASA } & \multirow{2}{*}{$\begin{array}{c}\text { Ages } \\
\text { Range/Median }\end{array}$} & \multirow[b]{2}{*}{ Male } & \multirow[b]{2}{*}{ Female } \\
\hline & I & II & & & \\
\hline \multicolumn{6}{|c|}{ Intravenous Drugs } \\
\hline $\begin{array}{l}\text { Ranitidine } \\
50 \mathrm{mg} \\
\text { B }\end{array}$ & 22 & 2 & $\begin{array}{c}17-51 \\
33\end{array}$ & 9 & 15 \\
\hline $\begin{array}{l}\text { Ranitidine } \\
100 \mathrm{mg} \\
\mathrm{C}^{1}\end{array}$ & 24 & 0 & $\begin{array}{c}18-56 \\
31\end{array}$ & 8 & 16 \\
\hline $\begin{array}{l}\text { Cimetidine } \\
300 \mathrm{mg}\end{array}$ & 18 & 6 & $\begin{array}{c}16-70 \\
36\end{array}$ & 11 & 13 \\
\hline $\begin{array}{l}\text { D } \\
\text { Placebo }\end{array}$ & 20 & 4 & $\begin{array}{c}20-72 \\
34\end{array}$ & 13 & 11 \\
\hline \multicolumn{6}{|l|}{$\begin{array}{l}\text { Oral Drugs } \\
\mathbf{E}\end{array}$} \\
\hline $\begin{array}{l}\text { Ranitidine } \\
150 \mathrm{mg} \\
\text { F }\end{array}$ & 20 & 4 & $\begin{array}{c}21-69 \\
36\end{array}$ & 10 & 14 \\
\hline $\begin{array}{l}\text { Cimetidine } \\
300 \mathrm{mg} \\
\mathrm{G}\end{array}$ & 21 & 3 & $\begin{array}{c}19-67 \\
33\end{array}$ & 12 & 12 \\
\hline Placebo & 20 & 4 & $\begin{array}{c}18-71 \\
33\end{array}$ & 9 & 15 \\
\hline
\end{tabular}

induction of anaesthesia and the contents of the stomach were aspirated. The volume of the aspirate was measured using a graduated cylinder and the $\mathrm{pH}$ of the gastric fluid was measured using a Fisher Accumet pH meter, Model 750 with a standard combination $\mathrm{pH}$ electrode. All $\mathrm{pH}$ values were measured in triplicate and then averaged before statistical analysis using the Student's t test.

\section{RESULTS}

Intravenous Groups (Table II)

\section{Ranitidine $50 \mathrm{mg}$ (Group A) or $100 \mathrm{mg}$ (Group B)}

There was one patient in each group with a $\mathrm{pH}$ below 2.5 (4 per cent). One patient in group A and one in Group B had a volume in excess of 25 $\mathrm{ml}$. No patient had both a $\mathrm{pH}$ less than 2.5 and a volume greater than $25 \mathrm{ml}$. There were two patients in each group with a pH less than 3.5 (8 per cent).

\section{Cimetidine $300 \mathrm{mg}$ (Group C)}

Two patients had a $\mathrm{pH}$ less than 2.5 (8 per cent). One of these also had a volume greater than $25 \mathrm{ml}$. A total of two patients had a volume in excess of $25 \mathrm{ml}$. There were no additional patients with a $\mathrm{pH}$ less than 3.5 . 
TABLE II

\begin{tabular}{|c|c|c|c|c|c|}
\hline Group & $\begin{array}{c}\text { Number } \\
\text { of Patients }\end{array}$ & $\begin{array}{l}\text { Volume } \\
>25 \mathrm{ml}\end{array}$ & pH Range & $\mathrm{pH}<2.5$ & $\mathrm{pH}<3.5$ \\
\hline \multicolumn{4}{|c|}{$\begin{array}{l}\text { Intravenous Drugs } \\
\text { A Ranitidine }\end{array}$} & \multicolumn{2}{|c|}{$\begin{array}{l}\text { Number } \\
\text { (per cent) }\end{array}$} \\
\hline $\begin{array}{l}50 \mathrm{mg} \\
\text { B Ranitidine }\end{array}$ & 24 & 1 & $1.407-8.264$ & $1(4)$ & $2(8)$ \\
\hline C $\stackrel{100 \mathrm{mg}}{\text { Cimetidine }}$ & 24 & 1 & $1.630-8.701$ & $1(4)$ & $2(8)$ \\
\hline $\begin{array}{l}300 \mathrm{mg} \\
\text { D Placebo }\end{array}$ & $\begin{array}{l}24 \\
24\end{array}$ & $\begin{array}{l}2 \\
4\end{array}$ & $\begin{array}{l}2.121-8.260 \\
1.116-7.709\end{array}$ & $\begin{array}{c}2(8) \\
18(79)\end{array}$ & $\begin{array}{c}2(8) \\
19(79)\end{array}$ \\
\hline $\begin{array}{l}\text { Oral Drugs } \\
\text { E Ranitidine }\end{array}$ & . & & & & \\
\hline F Cimetidine & 24 & 1 & $1.508-8.512$ & $2(8)$ & $4(17)$ \\
\hline G Placebo & $\begin{array}{l}24 \\
24\end{array}$ & $\begin{array}{l}1 \\
4\end{array}$ & $\begin{array}{l}1.426-8.709 \\
1.036-7.762\end{array}$ & $\begin{array}{r}6(25) \\
19(79)\end{array}$ & $\begin{array}{c}7(29) \\
21(87.5)\end{array}$ \\
\hline
\end{tabular}

\section{Placebo (Group D)}

A total of eighteen patients ( 75 per cent) had a $\mathrm{pH}$ less than 2.5. Four patients had a measured volume in excess of $25 \mathrm{ml}$. These four patients also had a $\mathrm{pH}$ less than 2.5 . One additional patient had a pH less than 3.5 ( 79 per cent).

There was no relationship between failure of either ranitidine or cimetidine to alter $\mathrm{pH}$ favourably and intravenous administration more than forty-five minutes before induction of anaesthesia. There was no statistically significant difference in $\mathrm{pH}$ between groups $\mathrm{A}$ and $\mathrm{B}$, or between groups $A$ or $B$ and $C$. There was a statistically significant difference in $\mathrm{pH}$ values obtained when comparing ranitidine (Group A) vs. placebo (Group D) ( $<<0.001$ ); ranitidine (Group B) vs. placebo (Group D) ( $<<0.001)$; cimetidine (Group C) vs. placebo (Group D) (p $<0.001$ ), when given as intravenous agents.

\section{Oral Groups (Table II)}

\section{Ranitidine $150 \mathrm{mg}$ (Group B)}

Two patients had a $\mathrm{pH}$ less than 2.5 ( 8 per cent) and in one of these patients, the measured volume exceeded $25 \mathrm{ml}$. Two additional patients had $\mathrm{pH}$ values less than 3.5 (17 per cent).

\section{Cimetidine $300 \mathrm{mg}$ (Group F)}

Six patients ( 25 per cent) had a pH less than 2.5. Two of these patients also had a gastric volume greater than $25 \mathrm{ml}$. One other patient had a pH less than 3.5 (29 per cent).

\section{Placebo (Group G)}

Nineteen patients had a pH less than $2.5(79$ per cent). Four patients had a volume greater than $25 \mathrm{ml}$ and in all of these the $\mathrm{pH}$ was less than 2.5. Two additional patients had a $\mathrm{pH}$ less than 3.5 ( 87.5 per cent).

There was no statistical difference between oral cimetidine (Group F) compared with oral ranitidine (Group E). However, compared to placebo (Group G), pH values in both $\mathrm{H}_{2}$ receptor antagonist groups were statistically significantly higher $(\mathrm{p}<0.001)$. Intravenous ranitidine (Group B) was statistically significantly better than cimetidine $300 \mathrm{mg}$ orally (Group F) in raising gastric $\mathrm{pH}(\mathrm{p}<0.01)$. Treatment failures were not related to the timing of the oral doses.

It should be noted that the measured gastric volumes may underestimate the amount present in the stomach, as no attempt was made to define gastric volume accurately, other than the initial aspiration. A dilution method for defining gastric volumes has been described but was not employed in this study. ${ }^{9}$

Side effects before induction of anaesthesia were noted only in the intravenous ranitidine groups. Itching and/or buming at the site of injection was not uncommon, occurring in 11 out of 48 patients. This usually subsided within 10 to 15 minutes of injection. One patient developed a macular rash with no wheals after injection of ranitidine, but this disappeared without treatment within 15 minutes. Nausea was a common complaint in the postoperative period in all groups of patients and therefore is more likely related to the anaesthesia and surgical procedure rather than to any drugs which might have been given preoperatively. 


\section{Discussion}

Patients at risk of acid aspiration pneumonitis include pregnant patients undergoing Caesarean section or other obstetrical surgical procedures, emergency patients in whom gastric emptying is often delayed and those patients who are morbidly obese. ${ }^{10}$ In addition, patients coming for elective surgery who have been fasting, especially on an outpatient basis, may also be at risk. ${ }^{9}$ Cimetidine is well established as a suitable premedicant to increase gastric $\mathrm{pH}$ and reduce gastric volume..$^{3,5,10-16}$ However, it may not be fully effective and needs to be given some time, probably at least three quarters of an hour, before induction of anaesthesia. In the field of obstetrics, there has been a general lack of knowledge of the effects of cimetidine on the foetus at term and it is only recently that studies of its use during pregnancy have been carried out without any adverse effects noted. ${ }^{17,18}$

In the present study, patients receiving either intravenous ranitidine ( 50 or $100 \mathrm{mg}$ ) or cimetidine (300 $\mathrm{mg}$ ) at least three-quarters of an hour before induction of anaesthesia had gastric $\mathrm{pH}$ in the range where the risk of developing aspiration pneumonitis is considered to be slight. Although two of 48 in the ranitidine group and two of 24 in the cimetidine group had a pH lower than 2.5 , it appears that intravenous administration of these drugs in fasting non-pregnant patients is an effective means of increasing gastric $\mathrm{pH}$ before anaesthesia and elective surgery. The intravenous dose of ranitidine was much less than the intravenous dose of cimetidine, showing the greater potency of ranitidine. In addition, the $50 \mathrm{mg}$ intravenous dose of ranitidine was just as effective as $100 \mathrm{mg}$ in altering gastric $\mathrm{pH}$ before induction of anaesthesia.

When given orally, ranitidine $150 \mathrm{mg}$ appears to be more effective than cimetidine $300 \mathrm{mg}$; however the difference is not statistically significant. Oral ranitidine $150 \mathrm{mg}$ is as effective in altering gastric $\mathrm{pH}$ when compared with intravenous ranitidine or cimetidine if given at least two hours before induction of anaesthesia.

Oral cimetidine was more effective in altering $\mathrm{pH}$ when compared to placebo, but it still left 25 per cent of patients with a $\mathrm{pH}$ of less than 2.5 when the drug was given between two and four hours before induction. Intravenous ranitidine $100 \mathrm{mg}$ was better than oral cimetidine in raising gastric $\mathrm{pH}$. The results of the present study are comparable with those reported recently by
Johnson and his colleagues, ${ }^{19}$ who showed that both cimetidine and ranitidine increase gastric pH significantly when compared to placebos.

Side effects have been reported with both intravenous and oral use of cimetidine. ${ }^{20-24}$ Long-term cimetidine treatment has been shown to alter hepatic drug metabolism, ${ }^{25}$ whereas ranitidine did not do so after short term continuous use; the possibility of prolonged anaesthetic drug effects in patients on cimetidine therapy must be kept in mind. ${ }^{26,27}$ However, single doses of cimetidine have not been associated with any significant side effects; similarly, no side effects have been reported after single doses of ranitidine. However this may represent the limited use of a new drug, and it remains to be seen what the true incidence of side effects may be. In the present study, burning and itching were noted not uncommonly in patients given intravenous ranitidine, but these resolved spontaneously. It is possible that this could have been prevented by slower intravenous injection or by dilution.

We conclude that ranitidine is a suitable compound for increasing gastric $\mathrm{pH}$ above the range believed to be associated with the risk of aspiration pneumonitis; in addition, gastric volume is reduced and this may also play a part in reducing this risk. Ranitidine may be given either intravenously or orally and is effective by either route. When given intravenously, there appeared to be little difference between ranitidine and cimetidine in the doses used in this study. In contrast, the intravenous administration of ranitidine appeared to be more effective when compared to oral cimetidine. In most studies, a $\mathrm{pH}$ value over 2.5 is quoted as being desirable. However, if Crawford' $\mathrm{s}^{2}$ suggestion of a lower limit of 3.5 is accepted, then there appear to be some patients always at potential risk, whether given cimetidine or ranitidine in any dose range studied to date. In this respect, vigorous administration of antacids may be more effective. ${ }^{28}$ In addition, when immediate induction of anaesthesia is required, the only means of altering gastric $\mathrm{pH}$ is by the use of oral antacids, since the minimum effective time for $\mathrm{H}_{2}$ receptor antag. onists, given either orally or intravenously, is 45 minutes. Finally, the use of any of these agents by no means obviates the need for skilled anaesthetists with adequate assistance and equipment, the use of the Sellick manoeuvre properly applied, and rapid tracheal intubation in those patients truly at risk of acid aspiration.

To date, we have only studied prepared 
patients who are not at any known risk of aspiration pneumonitis. It may be that the $\mathrm{H}_{2}$ receptor antagonist drugs react differently in patients who are at risk, such as emergencies, obstetrical patients and the morbidly obese. In addition, the alternative administration of $\mathrm{H}_{2}$ receptor antagonists intramuscularly should be considered. ${ }^{29}$

\section{ACKNOWLEDGEMENTS}

We wish to thank Mr. K.F. Read of Glaxo Canada Ltd. for supplying financial assistance and drugs for completion of the study, and Dr. Jan Davies for her editorial assistance. Also, we wish to extend a note of appreciation to the anaesthetic staff and residents of Foothills Hospital, Calgary in assisting in collecting samples during the study and to Mrs. A. Nicholson and Ms Yvette Lloyd for their secretarial help.

\section{REFERENCES}

1. Mendelson, C.L. The aspiration of stomach contents into the lungs during obstetric anesthesia. Am. J. Obstet. Gynecol. 52: 191 (1946).

2. Crawford, S. Cimetidine in elective Caesarian Section. Anaesthesia 36:641 (1981).

3. Foulkes, E. \& JeNkins, L.C. A comparative evaluation of cimetidine and sodium citrate to decrease gastric acidity: effectiveness at the time of induction of anaesthesia. Can. Anaesth. Soc. J. 28: 29 (1981)

4. ROSEN, M. Editorial. Anaesthesia 36: 145 (1981).

5. Husemeyer, R.P., DAVenport, H.T \& RAJASEKARAN, T. Cimetidine as a single oral dose for prophylaxis against Mendelson's syndrome. Anaesthesia 33: 775 (1978).

6. Kett, K., Aadland, E. \& Berstad, A Inhibition of gastric secretion in man with a new $\mathbf{H}_{2}$-receptor antagonist, ranitidine. Scand. J. Gastroenterology 15: 249 (1980).

7. Domschke, W., Lux, G. \& Domschke, S Gastric inhibitory action of $\mathrm{H}_{2}$-antagonists ranitidine and cimetidine. Lancet 1: 320 (1979).

8. Bradshaw, J. Ranitidine (AH 19065): a new potent selective $\mathrm{H}_{2}$-receptor antagonist. Proceedings of the British Pharm. Soc. 464P, April 4-6 (1979).

9. Ong, B.Y., Palahniuk, R.J. \& Cumming, M Gastric volume and $\mathrm{pH}$ in out-patients. Can Anaesth. Soc. J. 25: $36(1978)$

10. Wilson, S.L., Mantena, N.R. \& Halverson, J.D. Effect of atropine, glycopyrrolate and cimetidine on gastric secretions in morbidly obese patients. Anesth. Analg. 60:37 (1981).

11. Dobe, G., Jordan, M.J. \& Williams, J.G. Cimetidine in the prevention of pulmonary acid aspiration (Mendelson's) syndrome. Br. J. Anaesth. 51: 967 (1979).
12. Salmenpera, M., Korttilla, K. \& Kalima, T. Reduction of the risk of acid pulmonary aspiration in anaesthetized patients after cimetidine premedication. Acta. Anaesthesiol. Scand. 24: $25(1980)$

13. Toung, T. \& Cameron, J.L. Cimetidine as a preoperative medication to reduce the complications of aspiration of gastric contents. Surgery 87: 205 (1980).

14. Stoelting, R.K. Gastric fluid $\mathrm{pH}$ in patients receiving cimetidine Anesth. Analg. 57: 675 (1978).

15. Coombs, D.W., Hooper, D. \& Colton, T. Pre-anaesthetic cimetidine alteration of gastric fluid volume and $\mathrm{pH}$. Anesth. Analg. 58: 183 (1979).

16. KIRKEGAard, P., SORENSEN, O. \& KiRKEGAard, $P$. Cimetidine in the prevention of acid aspiration during anesthesia. Acta. Anaesthesiol. Scand. 24: 58 (1980).

17. McCaughey, W., Howe, J.P., Moore, J. \& DUNDEE, J.W. Cimetidine in elective Caesarean section. Anaesthesia 36: 167 (1981).

18. Howe, J.P., MCGowan, W.A.W., Moore, J., MCCAughey, W. \& DundeE, J.W. The placental transfer of cimetidine. Anaesthesia 36: 371 (1981).

19. Johnston, J.R., MCCAUghey, W., Wright, P.J., GAMBLE, J.A.S. \& DUNDEE, J.W. Increase in intragastric $\mathrm{pH}$ after cimetidine and ranitidine. Br.J. Anaesth. 53: 664P (1981).

20. Daubresse, J.C., Meunier, J.C. \& Ligny, G. Plasma prolactin and cimetidine. Lancet 1: 99 (1978).

21. Valcavi, R. Single oral dose of cimetidine and prolactin. Lancet 2: 528 (1978).

22. Cohen, J. \& Weetman, A.P. Life threatening arrhythmias and intravenous cimetidine. Br. Med. J. 51: 768 (1979)

23. Shaw, R.G., Mashford, M.L. \& Desmond, P.V. Cardiac artest after intravenous injection of cimetidine. Med. J. Aust. 2:629 (1980).

24. MAHON, W.A.\& KOLTON, M. Hypotension after intravenous cimetidine. Lancet $1: 828$ (1979).

25. Henry, D.A., MacDonald, I.A., KitchingMAN, G., Bell, G.D. \& LaNGMAN, M.J.S. Cimetidine and ranitidine: comparison of effects on hepatic drug metabolism. Br. Med. J. 281: 775 (1980).

26. KLOTZ, U. \& REIMANN, I. Delayed clearance of diazepam due to cimetidine. N. Engl. J. Med. 302: 1012 (1980)

27. Serlin, M.J., Sibeon, R.G., Breckenridge, A.M., Mossman, S., Williams, J.R.B., Atwood, J.L. \& Willoughay, J.M.T. Cimetidine: interaction with oral anticoagulants in man. Lancet 2: 317 (1979).

28. HuSEMEYER, R.P. \& DAVENPORT, H.T Elective Caesarian Section. A comparison of cimetidine and magnesium trisilicate mixture regimens. Br. J. Obstet. Gynecol. 87: 565 (1980).

29. GRAINGER, S.L., POUNDER, R.E. \& ThOMPSON, R.P.H. Intramuscular cimetidine is safe and acceptable. Br. Med. J. 282: 1431 (1981). 
RÉSUMÉ

Une étude comparative des antagonistes des récepteurs $\mathrm{H} 2$, la cimétidine et la ranitidine sur le $\mathrm{pH}$ et le volume gastrique a été réalisée sur 168 patients programmés pour une chirurgie réglée. Les médicaments ont été administrés de façon aléatoire soit par la voie intraveineuse (ranitidine $50 \mathrm{mg}$ ou $100 \mathrm{mg}$, la cimétidine $300 \mathrm{mg}$ ou placebo) soit par la voie orale (ranitidine $150 \mathrm{mg}$, cimétidine $300 \mathrm{mg}$ ou placebo). Les patients ont reçu la drogue ou le placebo 45 minutes à cinq heures avant l'intervention. Après l'induction de l'anesthésie, une sonde nasogastrique a été mise en place et le contenu stomachal aspiré. On en a mesuré le $\mathrm{pH}$ et le volume. Les patients qui recevaient ranitidine 50 ou $100 \mathrm{mg}$ ou cimétidine 300 mg par la voie veineuse avaient un $\mathrm{pH}$ plus élevé de façon significative que ceux qui avaient reçu le placebo mais huit pour cent avaient un $\mathrm{pH}$ de moins de 2.5: la cimétidine orale a été inférieure de façon significative à la ranitidine intraveineuse à la dose de $100 \mathrm{mg}$. Nous en concluons que l'administration intraveineuse de cimétidine ou ranitidine est une méthode acceptable pour diminuer le $\mathrm{pH}$ gastrique avant l'induction de l'anesthésie. Par la voie orale, la ranitidine nous a paru supérieure à la cimétidine aux doses utilisées. Les deux médicaments doivent être administrés au moins 45 minutes avant l'induction de l'anaesthésie pour être efficace; l'usage de ces médicaments pour diminuer le risque de l'aspiration pulmonaire n'exclut en aucune façon l'utilisation d'une technique anesthésique appropriée pour l'induction de l'anesthésie. 